\title{
Appearance, persistence, and potential control of enhanced biodegradation of iprodione and vinclozolin in the field
}

\author{
A Alfizar 1, C Martin 2, P Davet 1* \\ 1 Laboratoire de Biologie et Pathologie Végétale, INRA-ENSA, F-34060 Montpellier Cedex 1; \\ 2 Centre de Transfert Agri-Phyto Mediterranée, 19 avenue de Grande-Bretagne, F-66025 Perpignan Cedex, France
}

(Received 24 June 1992; accepted 29 September 1992 )

\begin{abstract}
Summary - In a market garden soil, iprodione or vinclozolin biodegradation was accelerated following only 1 application of the respective fungicides at the recommended field dosage $\left(750 \mathrm{~g} \mathrm{Al} \mathrm{ha}^{-1}\right)$. The degradation rates reached a maximum and then stabilized after 4 and 6 successive weekly treatments respectively. Very limited cross-degradation between iprodione and vinclozolin was observed. Six-wk soil solarization reduced enhanced biodegradation in our experimental plots and in commercial lettuce fields.
\end{abstract}

biodegradation / lettuce drop / iprodione / vinclozolin / soil solarization

Résumé - Apparition, persistance et possibilités de réduction de la biodégradation accélérée de l'iprodione et de la vinchlozoline en plein champ. Dans un sol maraicher de Montpellier, on observe une accélération de la biodégradation de liprodione ou de la vinchlozoline dès la deuxième application du fongicide à la dose normale d'emploi (750 g ma.ha- ${ }^{-1}$ ). Après de nouvelles applications, les taux de dégradation continuent à augmenter jusqu'à une valeur maximale. Ils paraissent ensuite se stabiliser après 4 traitements hebdomadaires successifs pour liprodione et 6 pour la vinchlozoline. On n'observe qu'une très faible dégradation de la vinchlozoline dans les parcelles précédemment traitées à liprodione, et réciproquement. Le taux de dégradation de ces imides cycliques est réduit de façon très appréciable après traitement du sol des parcelles expérimentales par solarisation pendant 6 semaines. La solarisation a également donné des résultats intéressants dans des champs de production commerciale de laitues.

biodégradation / pourriture du collet / laitue / iprodione / vinchlozoline / solarisation

\section{INTRODUCTION}

Enhanced biodegradation of the cyclic imide fungicides, iprodione and vinclozolin, associated with poor control of onion white rot (Sclerotium cepivorum Berk) and lettuce drop (Sclerotinia minor Jagger) has been demonstrated in the United Kingdom (Walker et al, 1986; Walker, 1987a) and France (Martin and Davet, 1986; Martin et al, 1991). This could become an important problem since no other fungicides are presently available. However, no field studies have been reported since Walker's 1986 paper. We thus designed the following experiments to collect data on the behaviour of iprodione and vinclozolin in natural conditions, under a Mediterra- nean climate, and to determine primary elements for a strategy of use.

\section{MATERIALS AND METHODS}

\section{Induction of enhanced biodegradation}

Fungicide applications were carried out in 1990 in a small, homogeneous, loamy-sand field at the École Nationale Supérieure Agronomique in Montpellier (France). The organic matter content of the field was $2 \%, \mathrm{pH}=6.8$. Previous crops were soybean (1989), garlic (1988), and wheat (1987). The field remained fallow during the experiments. Three adjacent $10-\mathrm{m}^{2}$ plots were established in the field. They were sprayed

\footnotetext{
* Correspondence and reprints
} 
weekly with $1 \mathrm{I}$ of either iprodione, vinclozolin or tapwater. Iprodione (3-(3,5-dichlorophenyl)- $\mathrm{N}$-isopropyl2,4-dioxoimidazolidine-1-carboxamide) and vinclozolin ((RS)-3-(3,5-dichlorophenyl)-5-methyl-5-vinyl1,3-oxazolidine-2,4-dione) were in the form of commercial $500-\mathrm{g} \mathrm{Al} \mathrm{kg}^{-1}$ wettable powder formulations: Rovral and Ronilan, respectively. They were used at the recommended dosage of $0.75 \mathrm{~g} \mathrm{Al} \mathrm{I}^{-1}$. Eight applications were carried out from the 16th of May to the 4th of July. Soil samples were taken for analysis just before each treatment. Samples were also collected $1,7,27,39$ and $52 \mathrm{wk}$ after the last application

\section{Sampling and sample incubation}

Five $150-\mathrm{ml}$ subsamples were randomly collected from the top $8 \mathrm{~cm}$ of the central part of each plot and then mixed together. If not immediately studied, samples were kept at $5{ }^{\circ} \mathrm{C}$ until analysis (duration of storage: $<1 \mathrm{wk}$ ). For analysis, the soil was ground and sieved through a 2-mm screen. Water content was determined by drying aliquots at $105^{\circ} \mathrm{C}$ for $8 \mathrm{~h}$. Aqueous suspensions of iprodione or vinclozolin were added to the sieved samples to obtain a final concentration of $50 \mathrm{mg} \mathrm{kg}^{-1}$ and a water content of $20 \%$ (corresponding to $\approx-0.1 \mathrm{M} \mathrm{Pa}$ ). The mixture was distributed between $8100-\mathrm{ml}$ flasks (25 g per flask), which were closed and incubated at $28{ }^{\circ} \mathrm{C}$. Fungicide degradation was estimated in duplicate flasks after $2,3,7$, and $14 \mathrm{~d}$.

\section{Estimating biodegradation}

Iprodione or vinclozolin biodegradation was estimated by measurement of 3,5-dichloroaniline, one of their metabolites. After extraction with acetone $(25 \mathrm{ml}$ per flask, $1 \mathrm{~h}$ stirring), 3,5-dichloroaniline was characterized by the colorimetric test of Walker (1987b). The 3,5-dichloroaniline content was calculated by comparison with a standard calibration curve after reading the optical density at $530 \mathrm{~nm}$. For each flask, each dosage was repeated twice. For each sample, the amount of 3,5-dichloroaniline was plotted against the incubation period $(2,3,7,14 \mathrm{~d})$. The value obtained for the area between the curve and the abscissae axis was named the "degradation index" (Martin et al, 1991) the higher and longer the production of 3,5dichloroaniline (expressing cyclic imide degradation), the higher the degradation index value.

\section{Study of cross-degradation}

One week after the eighth treatment, soil samples were collected from each plot. After sieving, each sample was divided into 2 parts: one of these subsamples was mixed with $50 \mathrm{mg} \mathrm{kg}^{-1}$ iprodione, and the other with $50 \mathrm{mg} \mathrm{kg}^{-1}$ vinclozolin. The mixtures were poured into $100-\mathrm{ml}$ flasks, treated as described above, and the degradation indices were calculated.

\section{Solarization}

Solar heating of soil was carried out as described by Katan (1981). One week after the eighth treatment, the experimental plots were copiously watered in order to reach field capacity at $50-60 \mathrm{~cm}$ depth. Half of each plot was then covered with a transparent $25-\mu \mathrm{m}$ thick polyethylene sheet, the edges of which were covered with soil so that it was stretched over the surface. The other half of each plot was left uncovered. Solarization lasted $6 \mathrm{wk}$, from July 11 to August 23. Soil samples were collected at the end of the experiment and degradation indices were determined as described above.

Trials were also carried out in 1990 and 1991 in the Perpignan region in commercial lettuce fields where iprodione had been regularly used for more than $3 \mathrm{yr}$. In each field; solarization was carried out on 4 separate $9 \times 5 \mathrm{~m}$ plots. This lasted $6 \mathrm{wk}$, from mid-July to the end of August. Twenty $150-\mathrm{ml}$ subsamples were collected (5 from each plot) and mixed together. A control sample was similarly constituted from nontreated parts of the field. In 1991, samples were collected 1 month after the end of solarization. In 1990 , they were collected 10 months later.

\section{In vitro soil heating}

Soil was sampled just before solarization from the iprodione-treated plot at Montpellier. Two hundred $\mathrm{g}$ sieved subsamples were autoclaved for $30 \mathrm{~min}$ at 50 , $55,70,100$ or $120^{\circ} \mathrm{C}$. Each portion was then mixed with iprodione to obtain a final concentration of $50 \mathrm{mg}$ $\mathrm{kg}^{-1}$, adjusted to $20 \%$ soil moisture, and equally distributed into $8100-\mathrm{ml}$ flasks. Flasks were maintained at $28{ }^{\circ} \mathrm{C}$ and 3,5 -dichloroaniline was measured after 2, 3, 7 and $14 \mathrm{~d}$ incubation.

\section{RESULTS}

\section{Induction of enhanced biodegradation}

In field conditions, the iprodione degradation index began to increase after only' one iprodione application (fig 1a). The index kept on rising after each treatment up to a maximum which was reached after the 4th application. It then seemed to stabilize at a plateau, regardless of the number of following treatments. The same trend was observed in the vinclozolin-treated plot, but it appeared later than in the iprodione-treated plot (fig 
1b). The degradation index remained very low in the control plot during the entire experiment.

\section{Persistence of biodegradation}

In the experimental plots, biodegradation remained high for at least 2 months after the last fungicide application. Then it slowly decreased during the winter and following spring. However, $1 \mathrm{yr}$ after the end of treatments, it was still higher than in the water-treated control plot (table l).

\section{Cross-degradation study}

Vinclozolin degraded slightly faster in the iprodione pre-treated soil than in the previouslyuntreated control soil, but its degradation index still remained much lower than the iprodione degradation index in these samples (table II). In the vinclozolin pre-treated soil, the iprodione degradation index was the same as in the control soil.

\section{Solarization}

Solar-heating the soil of experimental plots for 6 wh caused a substantial (but not complete) reduction of iprodione and vinclozolin biodegradation (table III). Moreover, in the solarized plots, biodegradation was delayed and became appreciable only after $14 \mathrm{~d}$ incubation.

In commercial lettuce fields, solarization reduced the degradation index at 4 of the 5 sites (table IV). There was no change in the Perpignan-1 field, but this could have been due to inadequate soil preparation before covering with plastic.

\section{Heating effect}

Heating biodegrading soil at 50 or $55^{\circ} \mathrm{C}$ did not change its degrading capacity. However, at $70^{\circ} \mathrm{C}$ and above, biodegradation was no longer observed (fig 2).

Table I. Temporal variations in the degradation index after soil treatment had been stopped. Treatment consisted of 8 weekly sprays with water or $0.75 \mathrm{~g} \mathrm{l}^{-1}$ fungicide.

\begin{tabular}{|c|c|c|c|c|c|c|}
\hline \multirow[t]{2}{*}{ Soil treatment } & \multirow[t]{2}{*}{ Sample incubation } & \multicolumn{5}{|c|}{ Time $(w k)$ after the last treatment } \\
\hline & & 1 & 7 & 27 & 39 & 52 \\
\hline Iprodione & Iprodione & 168 & 193 & 22 & 24 & 23 \\
\hline Water & Iprodione & 16 & 24 & 3 & 16 & 16 \\
\hline Vinclozolin & Vinclozolin & 165 & 84 & 15 & 17 & 32 \\
\hline Water & Vinclozolin & 12 & 7 & 2 & 13 & 14 \\
\hline
\end{tabular}
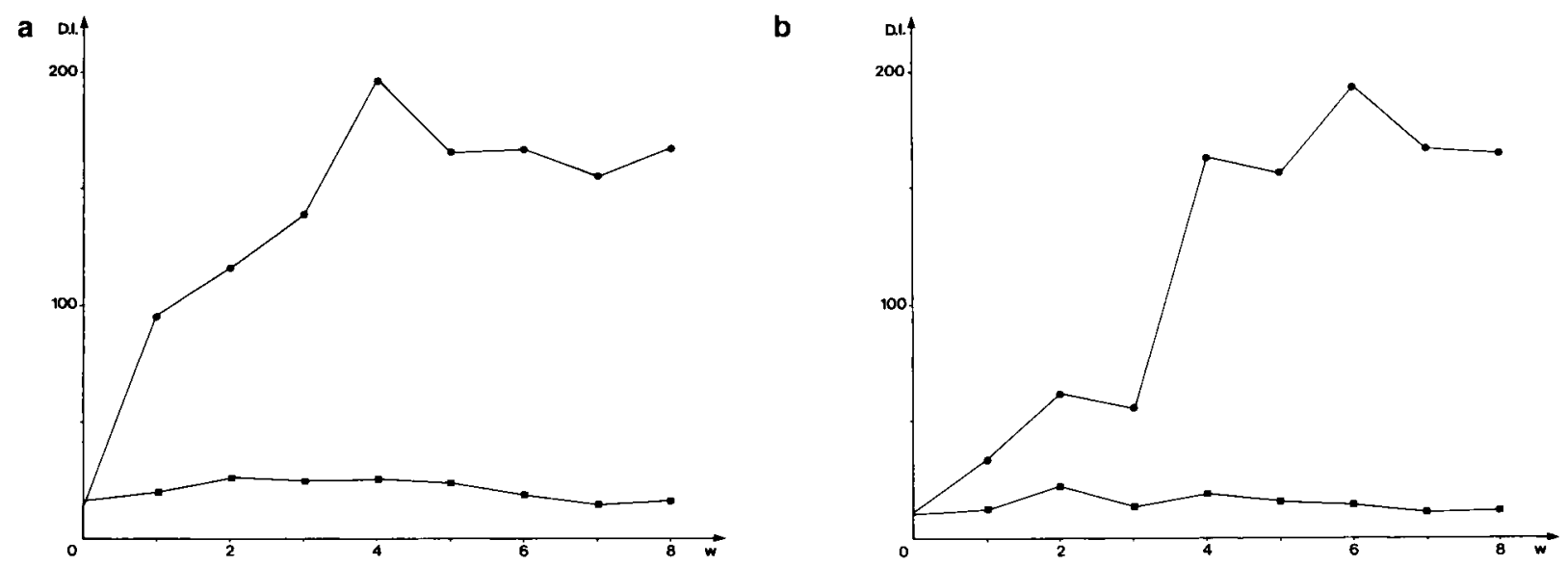

Fig 1. Evolution of iprodione (a) and vinclozolin (b) degradation indices with successive weekly treatments. $\bullet$, treatment with 0.75 gl-1 fungicide; $\boldsymbol{n}$, treatment with tap water. 
Table II. Lack of cross-degradation between iprodione and vinclozolin. Soil treatments were repeated 8 times with water or $0.75 \mathrm{~g} \mathrm{l}^{-1}$ fungicide. Samples, collected $1 \mathrm{wk}$ after the last treatment, were then incubated at $28^{\circ} \mathrm{C}$ with $50 \mathrm{mg} \mathrm{kg}^{-1}$ iprodione or vinclozolin.

\begin{tabular}{llc}
\hline Soil treatment & $\begin{array}{c}\text { Sample } \\
\text { incubation }\end{array}$ & $\begin{array}{c}\text { Degradation } \\
\text { index }\end{array}$ \\
\hline Iprodione & Iprodione & 224 \\
& Vinclozolin & 31 \\
Vinclozolin & Vinclozolin & 126 \\
& Iprodione & 26 \\
Water & Iprodione & 25 \\
& Vinclozolin & 13 \\
\hline
\end{tabular}

Table III. Effect of solarization in Montpellier experimental plots. Treatments before solarization consisted of 8 weekly sprays with water or $0.75 \mathrm{~g} \mathrm{I}^{-1}$ fungicide. Solarization lasted $6 \mathrm{wk}$.

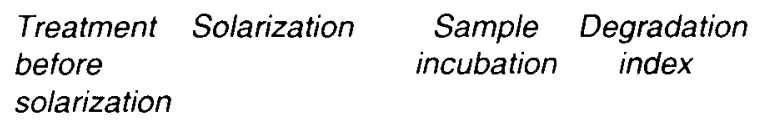

\begin{tabular}{lllr} 
& & & \\
Iprodione & Yes & Iprodione & 44 \\
Iprodione & No & Iprodione & 193 \\
Water & No & Iprodione & 24 \\
& & & \\
Vinclozolin & Yes & Vinclozolin & 42 \\
Vinclozolin & No & Vinclozolin & 84 \\
Water & No & Vinclozolin & 7 \\
\hline
\end{tabular}

Table IV. Effect of solarization in market-garden fields. Samples from 1990 and 1991 trials were analyzed 10 months and 1 month after solarization, respectively.

\begin{tabular}{|c|c|c|c|c|}
\hline \multirow{2}{*}{\multicolumn{2}{|c|}{ Location and date }} & \multicolumn{2}{|c|}{$\begin{array}{c}\text { lprodione } \\
\text { degradation index }\end{array}$} & \multirow[t]{2}{*}{$\%$ reduction } \\
\hline & & $\begin{array}{l}\text { Not } \\
\text { solarized }\end{array}$ & Solarized & \\
\hline Pézilla 1, & 1990 & 70 & 45 & 35.7 \\
\hline Perpignan 1 , & 1990 & 56 & 54 & 3.6 \\
\hline Pézilla 2, & 1991 & 184 & 58 & 68.5 \\
\hline Corneilla, & 1991 & 120 & 95 & 20.8 \\
\hline Perpignan 2, & 1991 & 43 & 14 & 67.4 \\
\hline
\end{tabular}

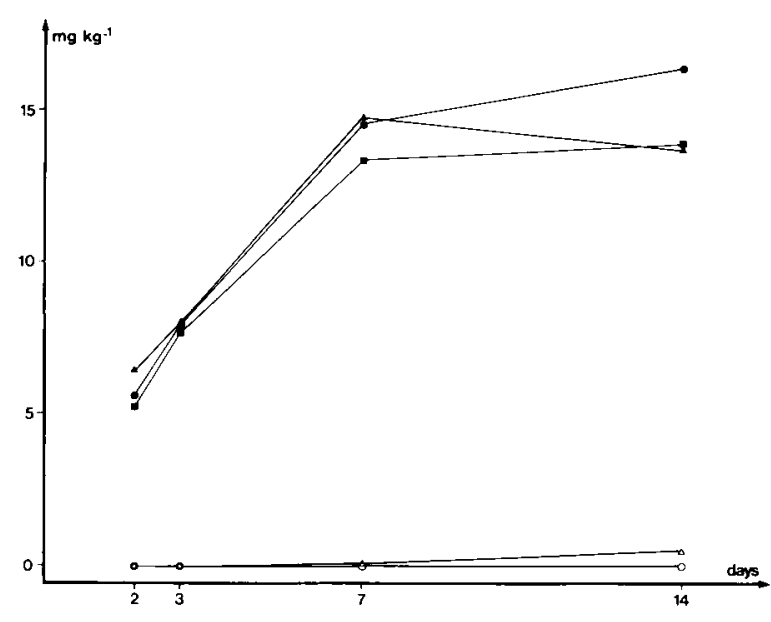

Fig 2. 3,5-Dichloroaniline formation after incubation of $50 \mathrm{mg}$ $\mathrm{kg}^{-1}$ iprodione in degrading soil samples previously heated in an autoclave for $30 \mathrm{~min}$ at $50^{\circ} \mathrm{C}(\bullet), 55^{\circ} \mathrm{C}(\boldsymbol{\square}), 70^{\circ} \mathrm{C}(\Delta)$, 100 or $120^{\circ} \mathrm{C}(\mathrm{O})$. Non-heated control : $\mathbf{\Delta}$.

\section{DISCUSSION}

These data are in agreement with the previous results of Walker et al (1986) and Walker (1987a), except that Walker's samples were incubated at $20^{\circ} \mathrm{C}$ and our samples at $28^{\circ} \mathrm{C}$, closer to Mediterranean climatic conditions. They also demonstrated that the iprodione or vinclozolin degradation rate could be increased as early as the second fungicide application. We further showed that the degradation index did not increase indefinitely, but reached a plateau after a limited number of applications: this seems to indicate that biodegrading microbial populations cannot multiply beyond ecologically defined limits. The existence of such limits has been demonstrated by Crozat et al (1982) for Bradyrhizobium japonicum. In our case, this could simply be due to lesser fungicide-substrate availability after multiplication of degrading bacteria, following repeated treatments.

There was no clear evidence of crossdegradation between iprodione and vinclozolin in our experiments. Whether different microorganisms or similar organisms with different plasmids are responsible for the degradation of iprodione and vinclozolin remains to be elucidated. Walker (1987a) found that the iprodione degradation rate was slower in vinclozolin pre-treated than in iprodione pre-treated soil, but it was still considerably faster than in previously-untreated control soil. General conclusions therefore cannot be 
drawn. Preliminary laboratory observations also showed no enhanced degradation of either iprodione or vinclozolin after pre-treatment of soil with procymidone (not published). Racke and Coats (1988) observed no cross-degradation between the organophosphorus insecticide isofenphos and 2 closely related molecules, chlorpyrifos and fonofos. Moreover, a pure culture of an isofenphos-degrading Arthrobacter sp was incapable of metabolizing the other 2 compounds.

Persistence of biodegrading properties differs considerably with soils. In Montpellier experimental plots, degradation rates appreciably decreased over time after fungicide applications had been stopped. This was an unexpected result since evidence of a much longer persistence was generally observed in other places, where at least 3 yr were necessary for recovery of the initial degradation rate (Martin et al, 1991). At the present time we have no explanation for this unusual behaviour.

Solarization is of special interest in Mediterranean and sub-arid countries. Yarden et al (1985, 1987) successfully used this process to prevent accelerated degradation of benomyl in Israel. In our experiments, it also proved to be a promising way of curing soils where enhanced biodegradation reduces the efficacy of iprodione or vinclozolin. In fact, solarization would have a double action in these problem soils, since it is also an effective means of controlling the target parasite, Sclerotinia minor. Soil temperatures were not recorded but previous experiments in similar conditions had revealed daily fluctuations between 30 and $45{ }^{\circ} \mathrm{C}$, with a few brief peaks at $50-55^{\circ} \mathrm{C}$ (Martin, 1991). We found that heating soil samples to $55^{\circ} \mathrm{C}$ for $30 \mathrm{~min}$ did not kill the bacteria since their biodegrading capabilities were not altered. However, exposure to heat induces changes in cellular metabolism, and production of large amounts of heat-shock proteins. Sublethally treated bacteria might have a lower ability to withstand competition and other stress factors, such as poor aeration under plastic (Katan et al, 1992). Sublethal heating could also modify the rate of plasmid transmission.

Another possibility of control, not treated in this paper, is the addition of chemical compounds: amendment with the fungicide thiram was shown to extend carbendazim persistence in soil (Yarden et al, 1987). Similarly, the addition of thiram to soil samples slowed down rapid degradation of iprodione or vinclozolin (Davet et al, 1990; Walker and Welch, 1991).
All these observations indicate that there is some potential for preventing or controlling accelerated degradation of cyclic imides. Crop rotation, alternate use of iprodione and vinclozolin, solarization, combination with other pesticides such as thiram should be considered as parts of a general strategy of integrated crop protection.

\section{REFERENCES}

Crozat Y, Cleyet-Marel JC, Giraud JJ, Obaton M (1982) Survival rates of Rhizobium japonicum populations introduced into different soils. Soil Biol Biochem 14, 401-405

Davet P, Martin C, Véga D, Alfizar A (1990) Biodégradation des imides cycliques dans le sol : quelques conséquences et quelques remèdes. $2^{e}$ Congrès Société Française de Phytopathologie, Montpellier, 28-30 nov 1990

Katan J (1981) Solar heating (solarization) of soil for control of soilborne pests. Annu Rev Phytopathol 19, 211-236

Katan J, Ginzburg C, Freeman S (1992) The weakening effect as a trigger for biological control and criteria for its evaluation. In: Biological Control of Plant Diseases (EC Tjamos, GC Papavizas, RJ Cook, eds) Plenum Press, New York, 55-61

Martin C (1991) La solarisation, méthode de désinfection des sols aux perspectives nouvelles. In: Les Plastiques en Agriculture. CPA-Rev Hortic 553566

Martin C, Davet $P$ (1986) Biodégradation d'imides cycliques dans le sol et différences d'efficacité pratique observées sur le Sclerotinia minor. Déf Vég 242, 26-29

Martin C, Davet P, Véga D, Coste C (1991) Field effectiveness and biodegradation of cyclic imides in lettuce field soils. Pestic Sci 32, 427-438

Racke KD, Coats JR (1988) Comparative degradation of organophosphorus insecticides in soil: specificity of enhanced microbial degradation. J Agric Food Chem 36, 193-199

Walker A, Brown PA, Entwistle AR (1986) Enhanced degradation of iprodione and vinclozolin in soil. Pestic Sci 17, 183-193

Walker A (1987a) Further observations on the enhanced degradation of iprodione and vinclozolin in soil. Pestic Sci 21, 219-231

Walker A (1987b) Enhanced degradation of iprodione and vinclozolin in soil: a simple colorimetric test for identification of rapid-degrading soils. Pestic Sci 21, 233-240

Walker A, Welch SJ (1991) Studies of the enhanced degradation of fungicides and herbicides in soils in the UK. EC Workshop: Accelerated Degradation of Soil-Applied Pesticides. Brussels, 12-13 dec 1991 
Yarden O, Katan J, Aharonson N, Ben-Yephet $Y$ (1985) Delayed and enhanced degradation of benomyl and carbendazim in disinfested and fungicidetreated soils. Phytopathology 75, 763-767
Yarden O, Aharonson N, Katan J (1987) Accelerated microbial degradation of methyl benzimidazol-2-ylcarbamate in soil and its control. Soil Biol Biochem $19,735-739$ 